\title{
ECONOMIC BURDEN OF TYPE 2 DIABETES MELLITUS AMONG THE PATIENTS ATTENDING COMBINED MILITARY HOSPITAL, DHAKA
}

\author{
Rahman $\mathrm{MZ}^{1}$, Islam $\mathrm{MZ}^{2}$, Alam $\mathrm{MJ}^{3}$, Sajjad $\mathrm{S}^{4}$, Ara ${ }^{5}$, Al-Azad MAS ${ }^{6}$, Kabir MA ${ }^{7}$
}

\begin{abstract}
Introduction: Diabetes Mellitus (DM) is a major concern for the developed as well as developing countries. It poses with enormous disabilities and economic burden to the victims. The treatment cost of diabetes is increasing day by day.
\end{abstract}

Aim: To ascertain how type 2 diabetes mellitus is incurring economic burden to the patients.

Materials and Methods: This descriptive cross sectional study was conducted during the period from January to June 2010 on 110 type 2 diabetes mellitus patients attending Combined Military Hospital, Dhaka. The patients were selected conveniently and data were collected by face to face interview with the help of a semi-structured questionnaire. For estimation of economic burden, both direct and indirect treatment costs were calculated.

Results: The study revealed that majority (36.4\%) of the patients were in the age group of 46-55 years with the mean age of $53.65(+10.44)$ years. Majority $(60.0 \%)$ of them had lower monthly family income (Tk.5, 000-Tk.10, 000) and 36.4\% of them lived in urban area. Most of the patients
(90.9\%) were under treatment with drug, diet control and physical exercise. Regarding sources of fund for treatment, $31.8 \%$ patients used their savings while $27.3 \%$ took loan, $20 \%$ got help from relatives and the remaining $20.9 \%$ got donation and sold wealth. Average treatment cost incurred by the patients was estimated to Tk. $5543.35(+1273.29)$. Average direct treatment cost was estimated to Tk.2656.88 (+1367.23) of which average drug cost was Tk.653.36 (+476.36), investigation cost was Tk.596.73 (+375.56), travel cost Tk.530.31 $(+795.46)$, attendant cost Tk.865.87 (+734.22) and consultation fee was Tk.244.48 (+167.22). Average indirect cost was calculated to Tk.3081.27 $(+1275.91)$ which was only due to loss of income due to illness.

Conclusion: The study findings will enable the health policy makers and health care providers at different levels to provide need based cost-effective health care services to reduce the economic burden of diabetes mellitus patients.

Key-Words: Economic Burden, Type 2 DM, Treatment cost

1. Maj Md Zahidur Rahman, MBBS, FCGP, MPH, SMO Sylhet Sector, BGB. 2. Dr. Md Ziaul Islam, MBBS, MPH, PGD, MSC (Health Economics), Assoc Prof, Dept of Community Medicine, NIPSOM, Mohakhali, Dhaka. 3. Lt Col Md Julfikkar Alam, MBBS, MPH, Mphil (PSM), AFMI, Dhaka Cantt. 4. Maj Shamima Sajjad (retd), MBBS, FCGP, FRSH, CCD, MPH (RCH). 5. Dr. Rowshan Ara, MBBS, MPH, M Phil, Asst. Prof, Dept of Community Medicine, DMC, Dhaka. 6. Lt Col Md Abdus Samad Al-Azad, MBBS, MCPS, DFM, Asst Prof, Forensic Medicine Dept, AFMC, Dhaka Cantt. 7. Lt Col Md Anwarul Kabir, MBBS, FCPS, DEM, Graded Spl in Medicine, $\mathrm{CMH}$, Dhaka. 


\section{Introduction}

Diabetes mellitus is a major concern for the developed as well as developing country like Bangladesh as it poses with enormous disabilities and economic burden to the victims. As an ice-berg disease prevalence of diabetes is more than five times higher at present than it was in the last decade. Currently the number of diabetic patients is estimated to be around 371 million globally in 2012 and this number is predicted to be double by 2025 , with the greatest number of cases being expected in developing countries ${ }^{1,2}$.

The treatment cost of diabetes to the patients and society is increasing many folds day by day. Bangladesh is in a far worse position than developed countries where treatment for diabetes is easily available. About $83 \%$ of the population of the country live on US $\$ 2$ a day and it's difficult for people to afford relevant care. But if the 3 million type 2 diabetes had access to free care, the number of years of life would double (5.8 million) and production value would triple ${ }^{3}$. The current prevalence rate of diabetes in Bangladesh is $9.51 \%$ and it is supposed to rise to more than $10 \%$ in 2025 and almost all are of type 2 DM. In a survey in 2003, documented that a prevalence of diabetes mellitus is $11.2 \%$ among city dwellers of Dhaka aged 20 years and above ${ }^{4}$. At present Bangladesh holds 10 th position and will occupy 7 th position with 11.1 million in 2030 in terms of number of diabetes patients in the world ${ }^{5}$.

As Armed Forces is the part and parcel of the large population of the country, therefore occurrence of any non communicable disease like diabetes in this community will bear the same impacts like a civil community. This study aims to determine the economic burden of type 2 DM patients among Armed Forces personnel who earn stipulated monthly salary and attend $\mathrm{CMH}$, Dhaka for treatment. The study findings in terms of different types of costs will enable the health policy makers and health care providers to formulate necessary strategies for providing need based cost-effective health care services to reduce economic burden of Armed Forces personnel who are suffering from type 2 DM patients.

\section{Methodology}

This was a cross sectional type of descriptive study. It was conducted on 110 type 2 diabetes mellitus patients among Armed Forces Personnel who attended Combined Military Hospital (CMH), Dhaka for treatment within the period covering January 2010 to June 2010. (Pregnant women who gave birth to baby from 1st July 2008 to 30th June 2009 are also icluded). Data collection was done by face to face interview from the respondents with the help of a pretested interview schedule. The data were compiled and analyzed by using SPSS 11.5 software.

\section{Results}

The Cross sectional study was conducted with an aim of exploring the economic burden of the type 2 diabetes mellitus patients. Results were formulated on the basis of selective variables and written as follows:

Table-l: Socio-demographic characteristics of type 2 DM patients.

\begin{tabular}{|ll|}
\hline Characteristics & \multicolumn{1}{c|}{ Findings } \\
Sex & male-91\%, Female-09\% \\
Age & mean age: 53.65 years $( \pm$ SD 10.44$)$ \\
Marital Status & Married-91.8\%, Widow/widower-5.5\%, Unmarried-2.7\% \\
Residence & Urban-36.4\%, sub-Urban-33.6\% \\
Education & SSC-37.3\%, Class Vl-X: $30 \%$, HSC-14.5\% \\
& Graduate- $9.1 \%$, Others- $9 \%$ \\
Occupation & Retired-50.0 $\%$, Service holders- $42.7 \%$, Housewife- $6.4 \%$ \\
Monthly income & Tk.9809.09 $( \pm$ SD-4235.01) \\
\hline
\end{tabular}


In respect of socio-demographic information, out of 110 patients most $(91.0 \%)$ were males and majority (36.4\%) were in the age group of $46-55$ years with the mean age of $53.65( \pm$ SD 10.44$)$ years. Most $(91.8 \%)$ of the patients were married and majority (36.4\%) came from urban area while half of them lived in semi-pucca houses. By education, majority (37.3\%) had SSC level educational qualification and by occupation 50.0 $\%$ of them were retired while $42.7 \%$ were in service and their average monthly family income was Tk.9809.09 $( \pm 4235.01)$ as shown in (Table-1).

Regarding type of treatment, most of the patients $(90.9 \%)$ were under drug, diet control and physical exercise (Table-11) and most $(88.0 \%)$ of them performed physical exercise with an average duration of $40.10 \pm 12.58$ minutes/days.

Table-Il: Distribution of the patients by the type of treatment received $(n=110)$.

\begin{tabular}{|l|l|l|}
\hline Teratment & $\begin{array}{c}\text { Number } \\
(\mathbf{n}=110)\end{array}$ & Percent \\
\hline Drug & 9 & 8.2 \\
\hline Both diet control \& Physical exercise & 1 & 0.9 \\
\hline Drug, diet control \& physical esercise & 100 & 90.9 \\
\hline Total & 110 & 100.0 \\
\hline
\end{tabular}

Regarding drugs, majority of the patients 63 (57.3\%) took oral hypoglycemic agents (Figure-1).

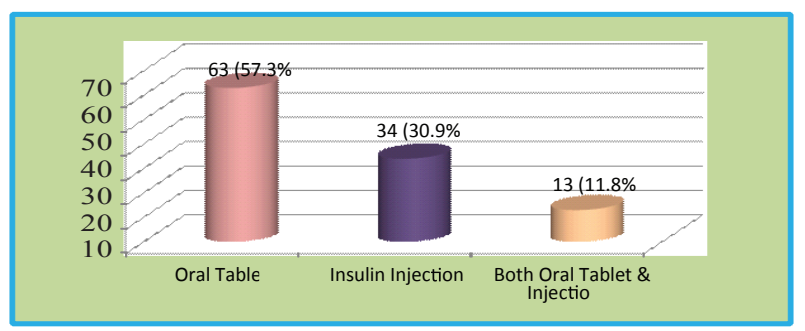

Fig-1: Type of drug taken by the patients

Among all, $40.0 \%$ patients had positive family history of diabetes and $45.5 \%$ of their parents had DM.
According to source of fund to maintain treatment cost, majority $(31.8 \%)$ used their savings while $27.3 \%$ took loan, $20 \%$ got help from relatives, $10.9 \%$ from donation and the $10 \%$ sold their valuable wealth (Table-11l).

Table-Ill: Distribution of the patients by sources of treatment cost $(n=110)$

\begin{tabular}{|l|c|c|}
\hline Sources & Number $(\mathrm{n}=110)$ & Percent \\
\hline Savings & 35 & 31.8 \\
\hline Selling wealth & 11 & 10.0 \\
\hline Taking loan & 30 & 27.3 \\
\hline Donation & 12 & 10.9 \\
\hline Help of relatives & 22 & 20.0 \\
\hline Total & $\mathbf{1 1 0}$ & $\mathbf{1 0 0 . 0}$ \\
\hline
\end{tabular}

Average treatment cost incurred by the patients was Tk.5543.35+1273.29 while average direct cost and average indirect cost was Tk.2656.88+1367.23 and Tk.3081.27+1275.91 respectively. In respect of different direct costs, average consultation fee was Tk.244.48+167.22, average cost of drug was Tk.653.36+476.36, average investigation cost was Tk.596.73+375.56, average travel cost was Tk.530.31+795.46 and average attendant cost was Tk.865.87+734.22. On the other hand, as an indirect cost, average loss of income of the patients was Tk.3081.18+1276.00 (Table-lV).

Table-IV: Distribution of the patients by total treatment cost (Monthly) $(\mathrm{n}=110)$

\begin{tabular}{|l|c|c|}
\hline Treatment cost (Tk.) & Number $(\mathrm{n}=110)$ & Percent \\
\hline $3000-4000$ & 15 & 13.6 \\
\hline $4000-5000$ & 22 & 20.0 \\
\hline $5000-6000$ & 30 & 27.3 \\
\hline $6000-7840$ & 43 & 39.1 \\
\hline Total & $\mathbf{1 1 0}$ & $\mathbf{1 0 0 . 0}$ \\
\hline
\end{tabular}

Mean \pm SD $=$ Tk. $5543.35 \pm 1273.29 \quad$ Range $=$ Tk.3000-Tk.7840

By sex, majority (43\%) of the male patients incurred higher treatment cost while majority of the female patients $(60 \%)$ incurred lower treatment cost and this difference of treatment cost by sex was statistically significant [ $(3)=23.393, \mathrm{p}<0.05]$ (Table-V). 
Table-V: Distribution of the patients by treatment cost and $\operatorname{sex}(n=110)$

\begin{tabular}{|c|c|c|c|}
\hline \multirow{2}{*}{$\begin{array}{l}\text { Treatment } \\
\text { cost (Taka) }\end{array}$} & \multicolumn{2}{|c|}{ Sex of the patients } & \multirow[t]{2}{*}{ Total } \\
\hline & Male (\%) & Female (\%) & \\
\hline $3000-4000$ & $\begin{array}{c}9 \\
(9.0 \%)\end{array}$ & $\begin{array}{c}6 \\
(60.0 \%)\end{array}$ & $\begin{array}{c}15 \\
(13.6 \%)\end{array}$ \\
\hline $4000-5000$ & $\begin{array}{c}19 \\
(19.0 \%)\end{array}$ & $\begin{array}{c}3 \\
(30.0 \%)\end{array}$ & $\begin{array}{c}22 \\
(20.0 \%)\end{array}$ \\
\hline $5000-6000$ & $\begin{array}{c}29 \\
(29.0 \%)\end{array}$ & $\begin{array}{c}1 \\
(10.0 \%)\end{array}$ & $\begin{array}{c}30 \\
(27.3 \%)\end{array}$ \\
\hline $6000-7840$ & $\begin{array}{c}43 \\
(43.0 \%)\end{array}$ & $\begin{array}{c}0 \\
(0.00 \%)\end{array}$ & $\begin{array}{c}43 \\
(39.1 \%)\end{array}$ \\
\hline Total & $\begin{array}{c}100 \\
(100.0 \%)\end{array}$ & $\begin{array}{c}10 \\
(100.0 \%)\end{array}$ & $\begin{array}{c}110 \\
(100.0 \%)\end{array}$ \\
\hline & & & $\mathrm{P}$ value $<.05$ \\
\hline
\end{tabular}

By occupation of the patients, majority (38.3\%) of service holders and majority of the retired patients $(45.5 \%)$ incurred higher treatment cost while majority of the house-wives, (71.4\%) incurred lower treatment cost and this variation of treatment cost by occupation was statistically significant $\left(X_{(9)}^{2}=28.06, \mathrm{p}<0.05\right)($ Table-Vl).

Table-Vl: Distribution of the patients by treatment cost and occupation $(\mathrm{n}=110)$

\begin{tabular}{|c|c|c|c|c|c|}
\hline \multirow[b]{2}{*}{$\begin{array}{l}\text { Treatment co: } \\
\text { (Taka) }\end{array}$} & \multicolumn{4}{|c|}{ Occupation of the Patients } & \multirow[b]{2}{*}{ Total } \\
\hline & $\begin{array}{c}\text { Service } \\
f(\%)\end{array}$ & $\begin{array}{c}\text { Farmer } \\
f(\%)\end{array}$ & $\begin{array}{c}\text { Housewife } \\
f(\%)\end{array}$ & $\begin{array}{c}\text { Retired } \\
f(\%)\end{array}$ & \\
\hline 30004000 & $\begin{array}{c}3 \\
(6.4 \%)\end{array}$ & $\begin{array}{c}0 \\
(0.00 \%)\end{array}$ & $\begin{array}{c}5 \\
(71.4 \%)\end{array}$ & $\begin{array}{c}7 \\
(12.7 \%)\end{array}$ & $\begin{array}{c}15 \\
(13.6 \%)\end{array}$ \\
\hline 40005000 & $\begin{array}{c}9 \\
(19.1 \%)\end{array}$ & $\begin{array}{c}0 \\
(0.00 \%)\end{array}$ & $\begin{array}{c}1 \\
(14.3 \%)\end{array}$ & $\begin{array}{c}12 \\
(21.8 \%)\end{array}$ & $\begin{array}{c}22 \\
(20.0 \%)\end{array}$ \\
\hline 50006000 & $\begin{array}{c}17 \\
(36.2 \%)\end{array}$ & $\begin{array}{c}1 \\
(100.0 \%)\end{array}$ & $(14.3 \%)$ & $\begin{array}{c}11 \\
(20.0 \%)\end{array}$ & $\begin{array}{l}30 \\
(27.3 \%)\end{array}$ \\
\hline 60007840 & $\begin{array}{c}18 \\
(38.3 \%)\end{array}$ & $\begin{array}{c}0 \\
(0.00 \%)\end{array}$ & $\begin{array}{c}0 \\
(0.00 \%)\end{array}$ & $\begin{array}{c}25 \\
(45.5 \%)\end{array}$ & $\begin{array}{c}43 \\
(39.1 \%)\end{array}$ \\
\hline Total & $\begin{array}{c}47 \\
(100 \%)\end{array}$ & $\begin{array}{c}1 \\
(100.0 \%)\end{array}$ & $\begin{array}{c}7 \\
(100.0 \%)\end{array}$ & $\begin{array}{c}55 \\
(100.0 \%)\end{array}$ & $\begin{array}{c}110 \\
(100.0 \%)\end{array}$ \\
\hline
\end{tabular}

\section{Discussion}

This cross sectional descriptive study was conducted among 110 diabetes patients who attended Combined Military Hospital, Dhaka. The aim of the study was to determine the economic burden of diabetic patients. Among 110 patients, majority i.e. $40(36.4 \%)$ of them were in the age group of $46-55$ years, followed by $33(30.0 \%)$ in the age group of 56-65 years with mean age 53.65 $( \pm 10.44)$ years. This clearly indicates that the group ( $>40$ years) is one of the risk factor for diabetes which was in consistence with the study by Ahmed $\mathrm{G} \mathrm{U}$ et $\mathrm{al}^{6}$. As per profession, majority $55(50 \%)$ were retired followed by service holders(42.7\%) and housewives (6.4\%). It was observed from the occupational findings that, prevalence of diabetes was more among those who were less exposed to physical activities. This observation was consistent with the findings by Azimi-Nezhad $\mathrm{M}$ et $\mathrm{al}^{7}$ and. Kelestimur $\mathrm{F}$ et $\mathrm{al}^{8}$. The study revealed that $60 \%$ were in low income group (Tk.5000 to 10000) with average income of Tk.9809.09 $( \pm 4235.01)$. Majority of the patients i.e. $40(36.4 \%)$ lived in urban area. A study by Sayeed M A et $\mathrm{al}^{9}$ (1997) observed that prevalence of type 2 diabetes was $6.7 \%$ and IGT $12.4 \%$ among urban population and the lowest prevalence was observed among the poor socioeconomic classes. The study was partially similar with this study. Dissimilarity was seen in economic status of the patients and which may be due to different study places.

Regarding type of therapy received by the patients, the study showed that out of 110 patients, majority i.e. $100(90.9 \%)$ were under drug, diet control and physical exercise. Most of the patients i.e. 97 (88 $\%$ performed physical exercise as recommended by the physician. The study also revealed that out of all patients, majority $63(57.3 \%)$ took oral tablet (OHA) where as $34(30.9 \%)$ took insulin injection and the remaining $13(11.8 \%)$ patients dependent on OHA and insulin. A study by Islam M Z et al ${ }^{10}$ concluded that $11.7 \%$ were on diet control and physical exercise and majority (50.6\%) patients were on OHA which was found similar with this study.

Regarding source of funding for treatment cost, the study showed that majority i.e. $35(31.8 \%)$ used savings for treatment while $30(27.3 \%)$ took loan, $22(20 \%)$ got help from relatives, 12 (10.9\%) from donation and remaining $11(10 \%)$ from sold wealth. Savings were the main source to meet the treatment cost among the patients. Average monthly direct cost for the disease was found to be Tk. 2656.88(+ 1367.23) which was not similar with the treatment cost of type 2 diabetes patient estimated in the study conducted by Islam $\mathrm{M} \mathrm{Z}$ et $\mathrm{al}^{10}$. (2008), where it was found to be Tk. 742.97 $(+593.36)$ and this deviation may be due to gradual increase of cost of drug, investigation, consultation fee and traveling expense with time (by these twoyears duration). Out of average monthly direct cost, average drug cost was Tk.653.36 (+476.36) while cost of investigation was Tk.596.73 
$(+476.56)$, travel cost was Tk.530.31 (+795.46), attendant cost was Tk.865.87 (+734.22) and Tk.244.48 (+167.22) was for consultation fee. The study conducted by Islam M Z et al ${ }^{10}$ revealed that drug cost was the highest among all direct costs which was identical with this study.

This study revealed that average monthly indirect cost was Tk. 3081.27(+1275.91) is loss of income due to illness. This study also showed that average monthly treatment cost was 5543.35(+ 1273.29).Out of this, average monthly direct cost for the disease was found to beTk.2656.88 (+ 1367.23) and indirect cost was Tk. 3081.27(+ 1275.91). This finding was similar with the study carried out by González J C, Walker J H and Einarson $\mathrm{T} \mathrm{R}$; in Columbia ${ }^{11}$. This study also revealed that there was no statisticaly significant association among the treatment cost with age, place of residence, monthly family income and source of funding for treatment of the patients. There was also no statistically significant association found between travel cost and place of residence of the patients. On the other hand there was statistical significant association between treatment cost with sex, marital status and occupation of the patients. As the prevalence of diabetes is increasing day by day, the overall economic burden of diabetic patients is also greatly rising. This study clearly indicates that, enormous economic burden imposed to the diabetic patients definitely reduces their capability to handle such a notorious deadly disease.

\section{Conclusion}

This descriptive cross-sectional study was conducted among type $2 \mathrm{DM}$ patients to ascertain economic burden of the disease and also to correlate these with socio-demographic characteristics of the patient. In this study it was reflected that prevalence of the disease was more among productive age group and majority had lower income. The studies also revealed that majority of the patients were retired and had SSC level education. Regarding therapy, most of them were under drug, diet control and physical exercise; among them, majority took oral tablet.
According to the sources for funding of treatment, majority used savings for their treatment. In respect of direct treatment cost, majority of the patients spent more money for attendant cost purpose and for purchasing drugs, while in indirect treatment cost, it is only the amount of loss of income due to illness. Average treatment cost incurred by the patients was found more as indirect treatment cost. There were significant association found between treatment cost with sex, marital status and occupation of the patients.

This study has addressed the economic magnitude of diabetes mellitus in army personnel and which definitely represents the situation in Bangladesh. Finally all those involved in diabetes care need to be aware of what drives cost. Demand for economic research will continue to be increased because of need to assess the growing number of interventions available such as free treatment cost, subsidy, health insurance etc. to minimize the cost incurred by the patients. To reduce economic burden

of

$\mathrm{DM}$, early diagnosis and prompt treatment along with adherence to diabetes therapy is essential. Overall awareness and health education are the prime need to combat this deadly disease as well as to overcome the economic burden of the disease.

\section{References}

1. Rashid KM, Khabir UM and Hyder S; Textbook of community medicine and public health, 4th ed. Dhaka (Bangladesh); R H M Publishers, 2004: 296- -302 .

2. Park K; Park's Textbook of preventive and social medicine, 19th ed. Jabalpur (India); Banarasi Bhanot Publishers, 2007: 327-32.

3. Azad AK, Mahtab H, Grant J, Steward M, Tofayel A and Haque J A; Diabetes mellitus, Epidemiology, 2nd ed, Diabetic Association of Bangladesh; Dhaka, 2007: 19-22. 
4. Emneus M, Björk S , Christiansen T and Green S; Presentation made at Global Forum 9, Mumbai, India, Full paper version of abstract no. 537; September 2005: 11-6.

\section{Sayeed M A, Epidemiology of Diabetes} Mellitus, 3rd ed. Dhaka, Evergreen Printing and Packaging; 2004: 23-9.

6. Ahmed G U, Zafrul H, Ataharul M I and Khan A $\mathrm{K} \mathrm{A}$; characteristics of the diabetes subject: BIRDEM Diabetes Registry 1985, Journal of Diabetic Association of Bangladesh, 1994; 22(2): 39-51.

7. Azimi-Nezhad M, Ghayour-Mobarhan M, Parizadeh M R, Safarian M, Esmaeili H, Parizadeh S M J, Khodaee G, Hosseini J, Abasalti Z, Hassankhani B and Ferns G; Prevalence of type 2 diabetes mellitus in Iran and its relationship with gender, urbanization, education, marital status and occupation, Original Article: Singapore medical journal 2008; 49(7):571.
8. Kelestimur F, Çetin M, Paşaoğlu H, Çoksevim B, Çetinkaya F, Ünlühizarci K, Ünal S and Köker A.H; The prevalence and identification of risk factors for type 2 diabetes mellitus and impaired glucose tolerance in Kayseri, central Anatolia, Turkey, Acta Diabetol, June 1999 ; 36(1-2): 85-91.

9. Sayeed M A, Ali L, Hussain MZ, Rumi MA, Banu A, Azad Khan AK, Effect of socioeconomic risk factors on the difference in prevalence of diabetes between rural and urban populations in Bangladesh. Diabetes Care, 1997 Apr; 20(4): 551-5

10. Ziaul Islam $M$ and Mansur Ahmed MSA; Burden of Type $2 \mathrm{DM}$ among the patients attending out-patient department of BIRDEM hospital, Dhaka: Journal of Preventive \& Social Medicine, June 2008; 27(1):17-29.

11. González J C, Walker J H and Einarson T R; Cost-of-illness study of type 2 diabetes mellitus in Colombia. Rev Panam Salud Publica, 2009; 26(1):55-63. 